J. Japan. Soc. Hort. Soc. 51(4) : 405-411. 1983

\title{
Changes in Endogenous Gibberellin Level in Strawberry Plants Induced by Light Breaks ${ }^{1}$
}

\author{
Yoshio Uematsu ${ }^{2}$ \\ Shizuoka Agricultural Experiment Station, Toyoda, Shizuoka 438 \\ Naoki Katsura \\ National Institute of Agricultural Sciences, Yatabe, Ibaraki 305
}

\begin{abstract}
Summary
Three-hour light break with a light intensity of 55 lux from 60-watt incandscent lamps increased the leaf growth of strawberry plants grown under natural short days of about 11 hours, and it was especially true when the light break was applied in the middle of the dark period.

The major gibberellin(GA)-like substance in the acidic ethyl acetate fraction extracted from strawberry leaves and crown was confirmed to be $\mathrm{GA}_{19}$ or a GA-like substance strikingly similar to $\mathrm{GA}_{19}$, by using thin-layer chromatography and dwarf rice bioassay.

The $\mathrm{GA}_{19}$-like substance level in plants treated with light break became higher than that in plants grown under natural short days after 9 days of treatment. But differences in the $\mathrm{GA}_{19}$-like substance level were not so clear among plants treated with light breaks at different times during the dark period. The possibility of GA turnover from the $\mathrm{GA}_{19}$-like substance to other $\mathrm{GAs}$ induced by light break was discussed.
\end{abstract}

\section{Introduction}

The forcing system of strawberry plants in Japan consists of autumn-planting and winter-harvesting. Temperature required for growth is provided by covering plants with a plastic film. The day-length of autumn and winter, however, induces so called relative dormancy(8) i.e. retardation of leaf growth under enough higher temperature conditions, and providing smaller yield of fruit. Then, application of gibberellin(GA) (5) and/or long day (LD) treatment by lighting $(9,10,20,21,22)$ have become popular techniques to prevent the relative dormancy.

Applications of GA and LD have similar effects in respect to increasing the vegetative growth $(3,7,17,19,21)$. Hence it is very reasonable to consider that an increased endogenous GA level induced by LD might

1 Received for publication July 7, 1982

2 Present address : Shizuoka Tohbu Agricultural Extension Office, Numazu 410 stimulate the leaf growth, as presented by Porlingis and Boynton(16). Although they indicated that further work was necessary to determine any relationship between amounts of the GA-like substances and day-length, this relationship has not been confirmed yet $(4,12,18)$. And endogenous GA-like substances in strawberry plants have also not been identified, though there are a few reports reffering to them $(1,6,13,16)$. This work was carried out in order to learn the characteristics of the major endogenous GAlike substances present in strawberry plants and to clarify the relationship between the changes in the endogenous GA-like substance level and the growth of strawberry leaves regulated by day-length.

\section{Materials and Methods}

\section{Plant materials}

Strawberry plants (Fragaria $\times$ ananassa Duch. cv. Hohkohwase) were grown by the method of forcing system as described pre. 


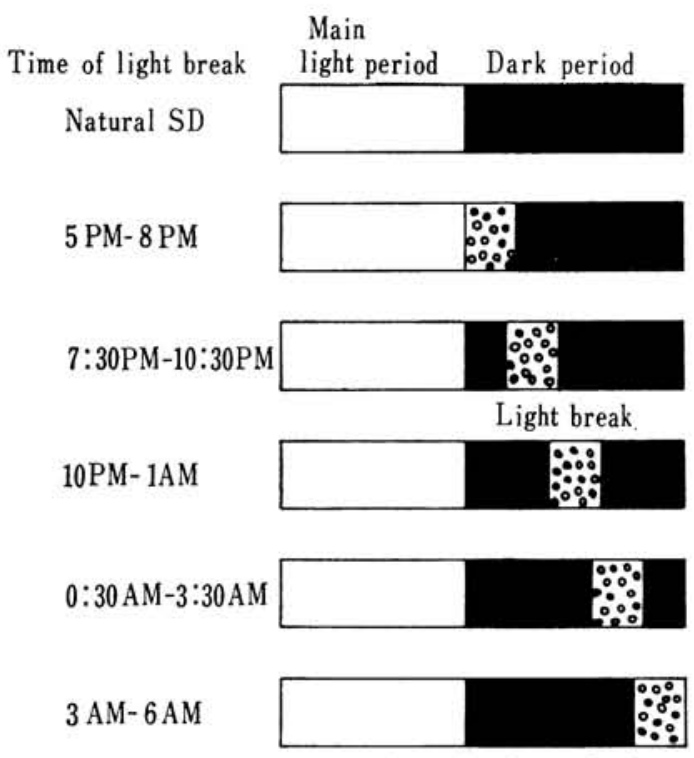

Fig. 1. Schedule of 3-hour light breaks applied at various times during the dark period.

Light was given from 60 -watt incandescent lamps at an intensity of $55 \mathrm{~lx}$.

viously(20). Plants were transplanted to the field on October 3 and protected by plastic houses beginning from October 15. Threehour light breaks as LD treatment, applied under natural short day conditions with about 11-hour day-length (Fig. 1), were started from October 20 and continued until the end of the experiment. A light intensity of about 55 lux at the top of the plants was provided from 60-watt incandescent lamps.

Extraction, fractionation and thin-layer chromatography ( $T L C$ )

Young leaves and upper $1 \mathrm{~cm}$ of crowns of strawberry plants were collected from the field and were used as materials for extraction of GA-like substances. The material was ground with $70 \%$ aqueous acetone 8 times its fresh weight. The mixture was left overnight at room temperature, and then filtered. After the filtrate was evaporated to remove acetone, the aqueous phase was adjusted to $\mathrm{pH} 2.5$ with phosphoric acid and was extracted 3 times with ethyl acetate. The ethyl acetate fraction was extracted 3 times with $0.75 \mathrm{M}$ phosphate buffer at $\mathrm{pH}$ 7.0. The buffer fraction was adjusted to $\mathrm{pH} 2.5$ with phosphoric acid and extracted
3 times with ethyl acetate. The acidic ethyl acetate fraction was dried over anhydrous sodium sulphate and evaporated to dryness.

The residue was redissolved in a small volume of acetone and applied as a narrow band to the starting line of a $20 \times 20 \mathrm{~cm}$ silica gel $(G)$ thin-layer plates with a thickness of $0.5 \mathrm{~mm}$. The chromatograms were developed using the following solvent systems : Isopropyl ether/acetic acid (95: 5, $\mathrm{v} / \mathrm{v})$; Isopropanol/water (4:1, v/v); Isopropanol/ammonia $(28 \%) /$ water $(10: 1: 1$, $\mathrm{v} / \mathrm{v}) ; \mathrm{n}$-Butanol/1.5 $\mathrm{N}$ ammonia $(3: 1, \mathrm{v} / \mathrm{v})$. The solvent was allowed to run $10 \mathrm{~cm}$ on the plate. After drying, the plates were divided into 10 equal zones from the starting line to the solvent front (the first zone was further subdivided into two zones). Each zone was scraped off and eluted 3 times with $2 \mathrm{ml}$ of $50 \%$ acetone. The eluates were reduced to dryness, and redissolved again in $0.1 \mathrm{ml}$ of $50 \%$ acetone for bioassay.

\section{Bioassay}

Bioassay was carried out by the method of microdrop application using dwarf rice cultivars, Tan-ginbozu and Waito-C as described by Murakami(14). The two dwarfs are known to have different sensibilities to different GAs. The former responds to various GAs, while the latter responds weakly to GAs having no $\mathrm{OH}$ group at the $\mathrm{C}-2$ position of the gibbane ring(14).

\section{Results}

Growth response of leaves to 3-hour light break.

Light break caused increased petiole elongation and increased leaf blade extension of newly formed leaves. Only leaf length was measured as an index showing the degree of leaf growth, since leaf length had been found to be highly correlated with petiole length or leaf area.

Plants treated with light break showed a slight growth increase after 9 days of treatment (Fig. 2). Differences in leaf growth due to the time of light break became clear after about 23 days of treatment. As previously reported(20), leaf growth was promoted most markedly when light break was 


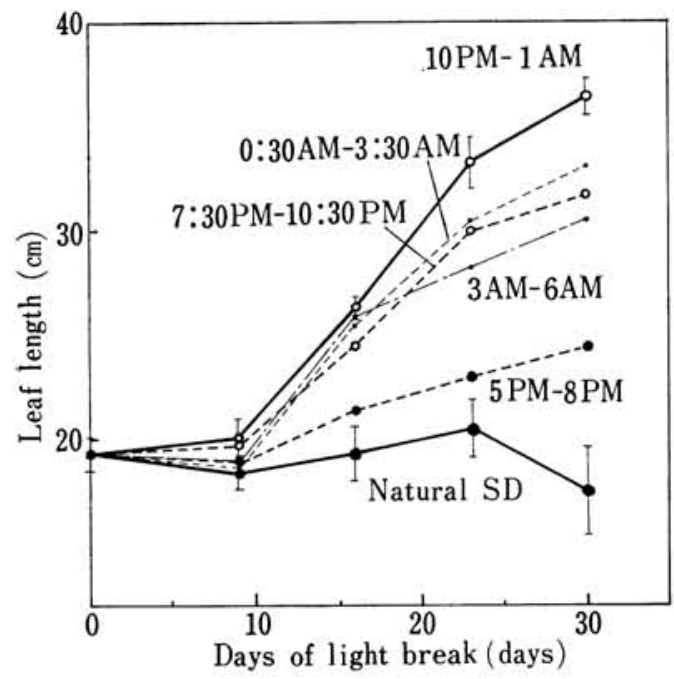

Fig. 2. Growth response of strawberry leaves to 3-hour light breaks applied at various times during the dark period.

Length of the 3 rd unfolded leaf (the 1 st is basal) was averaged for 5 plants.

applied at the middle of the dark period.

Characteristics of endogenous GA-like substance in leaves and crown.

Five plants grown under natural short days were used for one extraction. TLC was carried out using the solvent system, isopropyl ether/acetic acid $(95: 5, \mathrm{v} / \mathrm{v})$. The results from the bioassays are illustrated in Fig. 3. In the Tan-ginbozu assay, one peak of GA activity was always detected at $\mathrm{Rf}$ $0.05 \sim 0.2$, which corresponded to the known $\mathrm{Rf}$ value of $\mathrm{GA}_{3}$. But Waito-C dwarf did not respond to the extract of this zone.

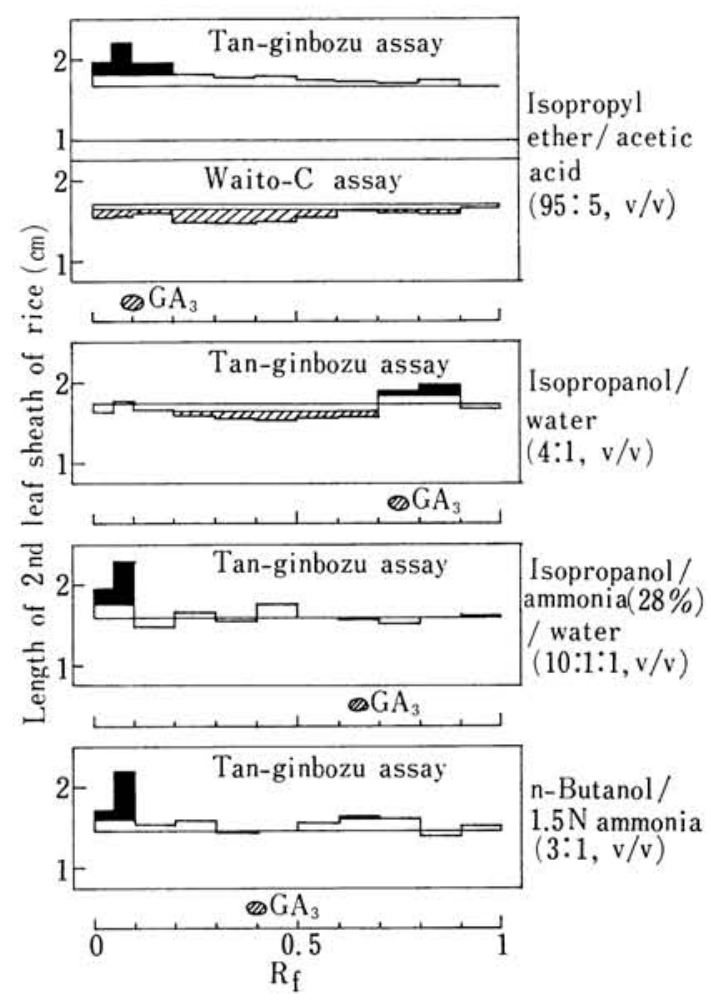

Fig. 4. Behavior of GA active zone in the extracts from strawberry leaves and crown following $T$. LC in 4 different solvent systems. Acidic ethyl acetate fraction extracted from 25 plants was chromatographed in the solvent system, isopro. pyl ether/acetic acid $(95: 5, \mathrm{v} / \mathrm{v})$. Then $R_{f} 0.05$ -0.3 zone was eluted in $50 \%$ acetone, divided into 4 aliquots. Each aliquot was chromato. graphed in each solvent system and was bioas. sayed using rice seedlings.

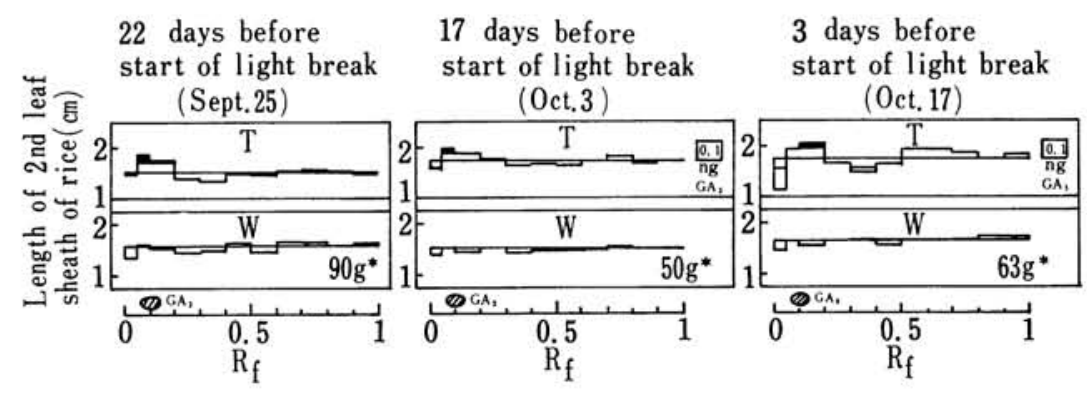

Fig. 3. GA activity in the extracts from strawberry leaves and crown following TLC in the solvent system, isopropyl ether/acetic acid (95: 5, $\mathrm{v} / \mathrm{v}$ ). Acidic ethyl acetate fractions extracted from 5 plants were chromatographed on silica gel (G). T, Tan-ginbozu assay. W, Waito-C assay. *Fresh weight of material. 
Table 1. Comparison of behavior of GA active zone in extracts from strawberry leaves and crown and from rice and bamboo shoots following thin-layer chromatography in 4 different solvent systems.

\begin{tabular}{|c|c|c|c|}
\hline Solvent system & $R_{f}$ of $\mathrm{GA}_{3}$ & Plant material & Zone of growth promotion ${ }^{z}$ \\
\hline Isopropyl ether/acetic acid $(95: 5, \mathrm{v} / \mathrm{v})$ & 0.1 & $\begin{array}{l}\text { Strawberry } \\
\text { Rice, Bamboo }\end{array}$ & $\begin{array}{l}0-0.2 \\
0.1-0.2\end{array}$ \\
\hline Isopropanol/water $(4: 1, \mathrm{v} / \mathrm{v})$ & 0.75 & $\begin{array}{l}\text { Strawberry } \\
\text { Rice, Bamboo }\end{array}$ & $\begin{array}{l}0.7-0.9 \\
0.7-0.9\end{array}$ \\
\hline $\begin{array}{l}\text { Isopropanol/ammonia(28\%)/ } \\
\text { water }(10: 1: 1, \mathrm{v} / \mathrm{v})\end{array}$ & 0.65 & $\begin{array}{l}\text { Strawberry } \\
\text { Rice, Bamboo }\end{array}$ & $\begin{array}{l}0-0.1 \\
0.05-0.2\end{array}$ \\
\hline$n$-Butanol/1.5 N ammonia $(3: 1, v / v)$ & 0.4 & $\begin{array}{l}\text { Strawberry } \\
\text { Rice, Bamboo }\end{array}$ & $\begin{array}{l}0-0.1 \\
0.05-0.1\end{array}$ \\
\hline
\end{tabular}

z Bioassay was carried out using the Tan-ginbozu dwarf of rice. Data of rice and bamboo used are those reported by Murakami (14).

After 9 days of light break
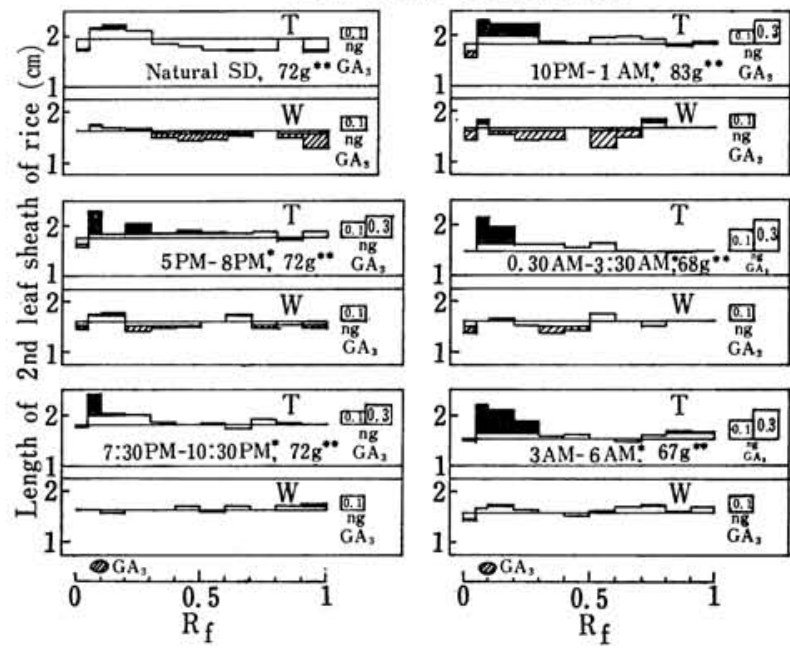

After 16 days of light break

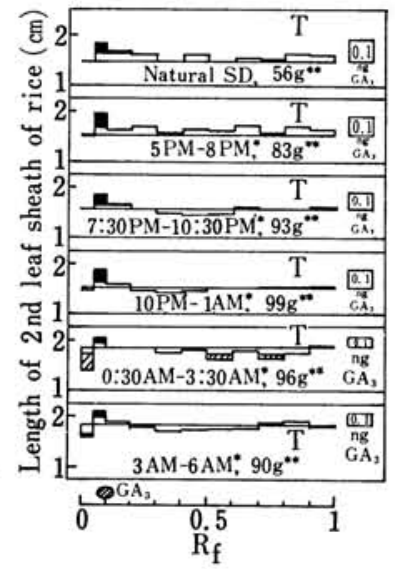

Fig. 5. Changes in GA level in strawberry plants induced by 3-hr light breaks. Acidic ethyl acetate fractions extracted from 5 plants were chromatographed on silica gel $(G)$ in the solvent system, isopropyl ether/acetic acid $(95: 5, \mathrm{v} / \mathrm{v})$. Bioassays were carried out by using rice seedlings. T, Tan-ginbozuassay. W, Waito-C assay. *Time of light break. **Fresh weight of material.

Next, the behavior of the active zone in the Tan-ginbozu assay in 4 chromatographic solvent systems was investigated. Twenty five plants treated with 3-hour light break (10 PM 1 $\mathrm{AM})$ for 30 days were used as material. From the chromatogram developed in the solvent system, isopropyl ether/acetic acid $(95: 5, \mathrm{v} / \mathrm{v})$, the zone at Rf $0.05 \sim 0.3$ was eluted in $50 \%$ acetone and divided into 4 aliquots. Each aliquot was chromatographed in 4 different solvent systems. The behavior of the active zone in each system is given in Fig. 4 and summarized in Table 1, in comparison to that of extracts from rice and bamboo reported by Murakami(14). In the Tan-ginbozu assay, $\mathrm{Rf}$ value of the active zone did not correspond to the known $\mathrm{Rf}$ value of $\mathrm{GA}_{3}$ in the solvent systems: isopropanol/28\% ammonia/water $(10: 1: 1, \mathrm{v} / \mathrm{v})$ and $\mathrm{n}$-butanol $1.5 \mathrm{~N}$ ammonia $(3: 1, \mathrm{v} / \mathrm{v})$. But the active zone behaved almost similarly to the extracts from rice and bamboo shoots in each system.

Changes in endogenous $G A$ level induced by light breaks.

Effect of light break on endogenous GA level was observed after 9 days of treatment. In the Tan-ginbozu assay, the extracts from 
plants treated with light break showed higher GA activity at $\mathrm{Rf} 0.05 \sim 0.3$ than those from plants grown under natural short days, but differences in the GA activity due to the time of light break were not clear (Fig. 5). in the Waito-C assay, weak activity was detected at the same Rf in some plots. After 16 days of treatment, however, no definite differences in GA activity due to the light break could be found in the Tan-ginbozu assay.

\section{Discussion}

Characteristics of endogenous GA-like substance in strawberry leaves and crown.

Acidic ethyl acetate fraction extracted from young leaves and crown of strawberry plants always showed one peak of GA activity at Rf $0.05 \sim 0.2$ in the Tan-ginbozu assay, when TLC was carried out using the solvent system, isopropyl ether/acetic acid (95:5, $\mathrm{v} / \mathrm{v}$ ). And Rf value of this zone corresponded to that of $\mathrm{GA}_{3}$. But the Waito-C dwarf did not respond to the extract of this zone. Since the Waito-C dwarf and the Tan-ginbozu dwarf respond to $\mathrm{GA}_{3}$ almost in the same manner(14), the activity present in this zone may not be due to $\mathrm{GA}_{3}$. This is supported by the result that the active zone differed in its behavior from $\mathrm{GA}_{3}$, when TLC was carried out using the solvent systems, isopropanol/ammonia (28\%)/ water (10:1 : 1 , $\mathrm{v} / \mathrm{v})$ and $\mathrm{n}$-butanol/1.5 $\mathrm{N}$ ammonia ( $3: 1$, $v / v)$. The behavior of the active zone in each of 4 different solvent systems was almost similar to that of the active zone from rice and bamboo shoots. It is known that the GA activity in the extracts from rice and bamboo shoots is due to $\operatorname{GA}_{19}(11,14,15)$. From these results major GA-like substance present in strawberry leaves and crown is confirmed to be $\mathrm{GA}_{19}$, known as bamboo GA, or a GA-like substance strikingly similar to $\mathrm{GA}_{19}$. It is reported by Porlingis and Boynton (16), Leshem and Koller(13) and Avigdoriavidov et al. (1) that 2 or 3 regions of GA activity appeared in the chromatogram loaded with extracts or diffusates of strawberry leaves, buds or crowns. And Goodwin and Gordon(6) presented evidence that different kinds of GA-like substances were present in the different parts of strawberry plants, but they did not identify the GA-like substances. Although no GA activities were found at $\mathrm{Rfs}$ other than that of $\mathrm{GA}_{19}$ in this experiment, further work is necessary to identify other minor GA-like substances in strawberry leaves, buds and crowns, because it is possible that they play some role in leaf growth.

Changes in endogenous $G A$ level induced by light breaks.

Strawberry leaf growth is regulated by day-length(20) as shown in this experiment. Differences in $\mathrm{GA}_{19}$-like substance levels were observed after 9 days of treatment between plants treated with and without light break under natural short days, but they were not observed among plants treated with light breaks at different times during the dark period. This supports the hypothesis that increased endogenous GA level induced by long days may stimulate leaf growth. However the results mentioned above also suggest that there is no quantitative relationship between the $\mathrm{GA}_{19}$-like substance level and the leaf growth when light breaks are applied at different times during the dark period. $\mathrm{GA}_{19}$ is thought to be generally inactive GA. Even if quantitative changes in the $\mathrm{GA}_{19}$-like substance level are found among the different photoperiodic conditions by using other minute methods, it is necessary for confirming the role of $\mathrm{GA}_{19}$-like substance as the regulatory system in photoperiodicity to demonstrate that the $\mathrm{GA}_{19}$-like substance extracted from strawberry plants shows activity in strawberry leaf growth. Zeevaart demonstrated that $\mathrm{GA}_{20}$, which is also thought to be generally inactive, showed higher activity than $\mathrm{GA}_{3}$ in spinach petiole elongation(25). So the possibility that the $\mathrm{GA}_{19}$-like substance has some effect on the growth of the strawberry leaf cannot be denied. Although the GA-turnover reported by Zeevaart(24), Clealand and Zeevaart(2) and Van den Ende and Zeevaart(23) could not be confirmed in this experiment, the turnover from the $\mathrm{GA}_{19}$-like substance to other active GAs also cannot be dinied, be- 
cause very weak but significant activity was detected in some plots in the Waito-C assay.

In the experiment reported here, we succeeded in making clear that LD treatment by light break induces the increase in the $\mathrm{GA}_{19^{-}}$ like substance level but failed to clarify the direct inter-relationship between endogenous GAs level and leaf growth of strawberry plants varying with the time of light break.

\section{Acknowledgement}

The authors are grateful to Dr. K. Inada and Dr. Y. Murakami of National Institute of Agricultural Sciences for their valuable suggestion in carrying out the present experiment.

\section{Literature Cited}

1. AVIGDORI-AVIDOV, H., E. E. GoldSCHMIDT and N. KEDAR. 1977. Involvement of endogenous gibberellins in the chilling requirements of strawberry (Fragaria $\times$ ananassa Duch.). Ann. Bot. 41: 927-936.

2. Clealand, C. F. and J. A. D. Zeevaart. 1970. Gibberellins in relation to flowering and stem elongation in the long day plant Silene armeria. Plant Physiol. 46:392-400.

3. DARROW, G. M. and G. F. WALDO. 1934. Responses of strawberry varieties and species to duration of the daily light period. Tech. Bull. U.S. Dept. Agr. $453: 31$.

4. ENDOH, M. and K. OHKAWA. 1974. Studies on the dormancy in strawberry plants. Endogenous GA-like substance and growth inhibitor. Abstr. Japan. Soc. Hort. Sci. Spring Meet. 206-207. (In Japanese)

5. Fujimoto, K. 1972. Studies on development of new cultivation system by clarifying physiological and ecological characteristics of strawberry plant cultivar 'Hohkohwase'. Special Research Bull. Nara Expt. Sta. 1: 97-99. (In Japanese)

6. GOODWIN, P. B. and A.GoRdon. 1972. The gibberellin-like substances and growth inhibitors in developing strawberry leaves. J. exp. Bot. $23: 970-979$.

7. GUtTRIDGe, C. G. and P. A. ThOMpson. 1964. The effect of gibberellins on growth and flowering of Fragaria and Duchesnea. J. exp. Bot. $15: 631-646$.

8. JONKERS, H. 1965. On the flower formation, the dormancy and the early forcing of strawberries. Meded. Land-bonwhogeschool, Wageningen. p. 65.

9. Kimura, M., T. Hisatomi and K. Fujimoto. 1968. Studies on the dormancy of strawberries. 1. The influence of daylength and CCC on the entrance of the dormancy. Bull. Nara Agr. Expt. Sta. 2:17-23. (In Japanese with English summary)

10. Kimura, M. and K. Fujimoto. 1971. Studies on the dormancy of strawberries. 2. The influence of daylength and temperature on the entrance of the dormancy. Bull. Nara Agr. Expt. Sta. 3:29-35. (In Japanese with English summary)

11. KuROGOCHI, S., N. MuROFUSHI, Y. OTA and N. TAKAHASHI. 1978. Gibberellins and inhibitors in the rice plant. Agr. Biol. Chem. 42 : 207-208.

12. LEE, B. Y. 1970. Dormancy in strawberry plants. Chemical Regulation of plants. 5 : 51-58. (In Japanese)

13. LESHEM, Y. and D. KolLER. 1966. The control of flowering in the strawberry Fragaria ananassa Duch. II. The role of gibberellins. Ann. Bot., N.S. $30: 587-595$.

14. Murakami, Y. 1970. New rice seedling test for gibberellins-Microdrop method. J. A. R. Q. 5. (2) : 5-9.

15. MUROFUSHI, N., S. IRIUCHIJIMA, N. TAKAHASHI, S. TAMURA, J. Kato, Y. WADA, E. WATANABE and T. AOYAMA. 1966. Isolation and structure of a novel $\mathrm{C}$ gibberellin in bamboo shoots. Agr. Biol. Chem. $30: 917-924$.

16. PORLingis, I. C. and D. BOYNTON. 1961. Evidence for the occurrence of gibberellinlike substances in strawberry. Proc. Amer. Soc. Hort. Sci. $78: 256-260$.

17. PORLINGIS, I. C. and D. BOYNTON. 1961. Growth response of the strawberry plant, Fragaria chiloensii var. Ananassa, to gibberellic acid and to environmental conditions. Proc. Amer. Soc. Hort. Sci. 78: 261-269.

18. SEYAMA, N., T. MASAKI and R. TAKAI. 1982. Studies on the development and the developmental periodicity of strawberry plant. 5 . The developmental phases and the rise and fall of endogenous growth regulators throughout the year. Abstr. Japan. Soc. Hort. Sci. Spring Meet. 228-229. (In Japanese)

19. ThOMPSON, P.A. and C. G. GutrRidge. 1959. Effect of gibberrellic acid on the initiation of flowers and runners in the strawberry. Nature, Lond. 184: $72-73$.

20. Uematsu, Y., M. SADA and S. HagiWARA. 1979. 
Studies on the regulation on growth of strawberry plants (Fragaria ananassa Duch.) in lighting culture. I. Regulation of the growth of leaves and flower formation of strawberry plants with light treatments. Bull. Shizuoka Agr. Expt. Sta. 24:54-60. (In Japanese with English summary)

21. UENO, Y. 1962. Flowering and vegetative growth of strawberry. I. Effect of photoperiod under constant temperature conditions. J. Japan. Soc. Hort. Sci. $31: 81-85$. (In Japanese with English summary)

22. UENO, Y., M. ITO and J. MATSUKAWA. 1962. Flowering and vegetative growth of straw- berry. II. Influence of "Light break" effect. J. Japan. Soc. Hort. Sci. $31: 168-172$. (In Japanese with English summary)

23. VAN DEN ENDE, $H$. and J. A. D. ZEEVAART. 1971. Influence of daylength on gibberellin metabolism and stem growth in Silene armeria. Planta (Berl.). 98:164-176.

24. ZEEVAART, J. A. D. 1971. Effects of photoperiod on growth rate and endogenous gibberellins in the long-day rosette plant spinach. Plant Physiol. $47: 821-827$.

25. ZeEvaART, J. A. D. 1975. In : Plant growth substances. 1973. Hirokawa Pub. Co. Tokyo. p. 1175 .

\title{
イチゴ内生ジベレリンの活性に及ぼす光中断の影響
}

\author{
植 松 徳 雄 \\ 静岡県農業試験場 438 静岡県磐田郡豊田町 \\ 桂 直 樹 \\ 齿林水産省農業技術研究所 305 茨城県筑波郡谷田部田
}

\begin{abstract}
摘 要
長日によって促進されるイチゴの菜の生長反応にジへ レリンが関与しているか知るため, 白熱灯により暗期内 の種々の時間帯に 3 時間の光中断を行ったときの内生シ ベレリンの活性の変化を调查した。

葉の生長に光中断の影響が現われ始めたのは処理開始 後 9 日目頃であった. その後, 処理間に差が認められる ようになり，葉の生長は暗期の中央の光中断区で最む促 進された.

薄層クロマトクラフィとイネ苗テストを用いた結果, イチゴ茎葉から抽出した酸性䣫酸エチル分画に含まれる ジベレリン様物質のうち主要なむのは, $\mathrm{GA}_{19}$, むしくは

これに極めて類似した物質と考えられた。

光中断処理区における $\mathrm{GA}_{19}$ 様物質の活珄は, 処理開 始後 9 日目に調査したとき自然短日区より增加していた が処理区間差は明らかでなかった．したがって，イチゴ の葉の生長反応を $\mathrm{GA}_{19}$ 样物質の量的変化のみに基づく ものと説明することは困難と考えられる. 同じ処理開始 後 9 日目には，一般的には活性が低いと考えられている $\mathrm{GA}_{19}$ 样物質の一部が他の活性型のジベレリンに転換し た可能性を, わずかではあるがらかがわせる結果が得ら れたことから、イチゴの葉の生長における活性型のジへ レリンの同定, 定量が必要と考えられた.
\end{abstract}

